\title{
Optimization Design of the Level of 70T Concentrated Nitric Acid Tank
}

\author{
Song Cang \\ Guidaojiaotong Polytechnic Institute, Shenyang 110023, China
}

Key word: Concentrated nitric acid tank; structure; strength;optimization design

\begin{abstract}
In this dissertation, an integrated factorial design about 70T Concentrated nitric acid tank is researched and implemented. Through the computation analysis of the body strength and its overall design of the frame, we get the improvements and optimization design scheme to its structural design.
\end{abstract}

\section{Introduction}

Nitric acid medium is a kind chemical substances with strong corrosive. So, in the course of carriage, need to use good aluminum truck anticorrosion performance. In order to meet the requirements of China's domestic nitric acid transportation market, We summarized the domestic aluminum tanker development experience, draw lessons from the developed countries aluminum tank car and mature technology, design and develop the $70 \mathrm{~T}$ aluminum rail tanker nitric acid.

\section{Development goal}

(1) Suitable for transportation density is not greater than $1.5 \mathrm{t} / / \mathrm{m}^{3}$, have strong corrosive nitric acid, hydrogen peroxide and other chemical products[1];

(2) Carrying capacity :70T, Dead weight: 26T;

(3) Axle load:25T;

(4) Commercial travel speed is $120 \mathrm{~km} / \mathrm{h}$;

(5) In accordance with the existing ground handling facilities.

3. The selection of main technical parameters and instructions

Carrying capacity and Dead weight. The density of aluminum is $2.7 \mathrm{t} / \mathrm{m} 3$, calculated tank wall thickness is $24 \mathrm{~mm}$. Calculated in accordance with the axle load is $23_{-1 \%}^{+2 \%} \mathrm{~T}$; the vehicle's load can be up to $70 \mathrm{~T}$, the vehicle's weight $\leqslant 26 \mathrm{~T}$.

Table 1 Vehicle performance parameters

\begin{tabular}{ccccc}
\hline $\begin{array}{c}\text { specific } \\
\text { volume }\end{array}$ & $\begin{array}{c}\text { load per } \\
\text { meter }\end{array}$ & $\begin{array}{c}\text { Commercial } \\
\text { operation speed }\end{array}$ & $\begin{array}{c}\text { minimum radius } \\
\text { of curvature }\end{array}$ & vehicle gauge \\
\hline $0.729 \mathrm{~m}^{3} / \mathrm{t}$ & $6.97 \mathrm{t}$ & $120 \mathrm{~km} / \mathrm{h}$ & $145 \mathrm{~m}$ & GB146.1-83 \\
\hline
\end{tabular}

Tank volume and vehicle length and width. Determination of the volume of tanks is based on the typical medium( $98 \%$ concentrated nitric acid), At the same time, the need to consider other medium. Determine the total volume of $49.6 \mathrm{~m}^{3}$, The effective volume of $46.7 \mathrm{~m}^{3}$, cavity volume of $6 \%$.

The last generation of conveying aluminum $\operatorname{tank}\left(\operatorname{Load} 60 \mathrm{~T}\right.$ capacity $\left.40 \mathrm{~m}^{3}\right)$ vehicle distance is $7300 \mathrm{~mm}, 70 \mathrm{~T}$ aluminum tank truck on this basis, increased by $1000 \mathrm{~mm}$ in length, vehicle distance to $8300 \mathrm{~mm}$, to improve vehicle curve through performance.

The tanker vehicle length is $13466 \mathrm{~mm}$. Generally, an aluminum tank car loading and unloading 
platform is shorter, and without the marshaling loading and unloading, so the vehicle length can be used in the user's existing ground handling facilities.

Because the material of tank is aluminum, the NSW manual brake should decorate the top of the beam on the one end, chassis width is $2680 \mathrm{~mm}$.

Table 2 Design parameters of tank

\begin{tabular}{|c|c|c|c|c|c|c|}
\hline project & $\begin{array}{l}\text { design } \\
\text { pressure }\end{array}$ & $\begin{array}{c}\text { design } \\
\text { temperature }\end{array}$ & $\begin{array}{l}\text { corrosion } \\
\text { allowance }\end{array}$ & $\begin{array}{c}\text { inner } \\
\text { diameter }\end{array}$ & texture & $\begin{array}{c}\text { ydrostatic } \\
\text { test }\end{array}$ \\
\hline unit & $\mathrm{MPa}$ & ${ }^{\circ} \mathrm{C}$ & $\mathrm{mm}$ & $\mathrm{mm}$ & & \\
\hline index & $\begin{array}{l}\text { ordinary } \\
\text { pressure }\end{array}$ & 40 & 1.5 & $\Phi 2400$ & $\begin{array}{l}1050 \mathrm{~A} \\
/ 5083\end{array}$ & 0.3 \\
\hline \multicolumn{7}{|c|}{ Table 3 main dimension } \\
\hline $\begin{array}{l}\text { vehicle } \\
\text { length }\end{array}$ & $\begin{array}{l}\text { vehicle } \\
\text { height }\end{array}$ & $\begin{array}{l}\text { Vehicle } \\
\text { width }\end{array}$ & $\begin{array}{l}\text { length } \\
\text { over end } \\
\text { sills }\end{array}$ & $\begin{array}{l}\text { coupler } \\
\text { height }\end{array}$ & $\begin{array}{l}\text { fixed axles } \\
\text { distance }\end{array}$ & $\begin{array}{c}\text { wheel } \\
\text { diameter }\end{array}$ \\
\hline $13466 \mathrm{~mm}$ & $4200 \mathrm{~mm}$ & $2680 \mathrm{~mm}$ & $12500 \mathrm{~mm}$ & $880 \pm 10 \mathrm{~mm}$ & $1830 \mathrm{~mm}$ & $840 \mathrm{~mm}$ \\
\hline
\end{tabular}

The choice of tank material. Aluminum tank material selection is one of the keys to the truck design. Due to the particularity of $98 \%$ nitric acid medium, can carry $98 \%$ nitric acid metal materials can only use pure aluminum material, In all pure aluminum material, Due to the excellent weldability, corrosion resistance and mechanical properties is moderate of $1 \mathrm{XXX}$ aluminum, which is widely used in the field of chemical container, railway tank truck.

With the requirements of the assessment of longitudinal force level 70T truck, the truck load increasing, the use of railway wagon condition is more and more bad, the mechanical properties of 1060 aluminum index is slightly lower. By the finite element strength analysis and calculation, if continue to use this material, it must increase the wall thickness of tank. At the same time, the main load-bearing structure need to be further strengthened, which caused the increase of light weight, low load, vehicle manufacturing costs increase, decline in the economic and technical indexes. So it is necessary to choose a more ideal pure aluminium material, make it should not only satisfy the requirements of the grade $70 \mathrm{~T}$ truck, and has high economic and technical index.

For chemical products such as nitric acid, 1XXX series of pure aluminum has excellent corrosion resistance. There are many years' experience with material such as 1060 and 1060A Chemical containers, rail tanker etc. The aluminum mechanical properties of 1050a, 1060 shown in the table below:

Table 4 The mechanical properties of 1050A,1060 aluminum

\begin{tabular}{cccccc}
\hline Material & $\begin{array}{c}\text { Thickness } \\
(\mathrm{mm})\end{array}$ & $\begin{array}{c}\sigma \mathrm{b} \\
(\mathrm{MPa})\end{array}$ & $\begin{array}{c}\sigma \mathrm{p}_{0.2} \\
(\mathrm{MPa})\end{array}$ & Permissible stress & $\begin{array}{c}\text { Elongation } \\
(\%)\end{array}$ \\
\hline $1050 \mathrm{~A}$ & $12.5 \sim 25$ & 70 & 35 & 17 & 16 \\
1060 & $12.5 \sim 50$ & 60 & 25 & 15 & 20 \\
\hline
\end{tabular}

The method of choosing the material allowable stress according to the regulations of the $\mathrm{TB} / \mathrm{T} 1335-1996$, With material $\sigma \mathrm{p}_{0.2}$ as a benchmark of material allowable stress value shown in the table below:

Table5 The allowable stress of material value

\begin{tabular}{ccc}
\hline Material & The first condition (MPa) & The second condition (MPa) \\
\hline $1050 \mathrm{~A}$ & 17 & 31.3 \\
1060 & 15.9 & 22.3 \\
\hline
\end{tabular}

Data show that the mechanical indexes of $1050 \mathrm{~A}$ is higher than 1060 . In order to confirm the 
weldability and manufacturability of 1050A, company's technology department many times communication with aluminum enterprises technical personnel, has made the welding procedure test and evaluation on the material, the results show that the model 1050A can satisfy the requirement of the railway tank truck manufacture process.

\section{The main structure design}

The structure of tank truck chassis is centre sill. The components of the tank truck are: tank, the ladder and the roof platform, chassis, chassis affiliated parts, brake device, coupler buffer device and bogie. The one end of the vehicle has passed, upper loading and unloading.

Tank. Using cylindrical shell and standard ellipsoidal head welding into tanks. There are six $120 \mathrm{~mm} \times 60 \mathrm{~mm} \times 20 \mathrm{~mm}$ and two $800 \mathrm{~mm} \times 80 \mathrm{~mm} \times 24 \mathrm{~mm}$ stiffening ring inside the tank, in order to improve the carrying capacity of the tank, cylinder material for aluminum head for aluminum alloy plate lining. The top of the tank is equipped with a DN500 manhole and a nitrate exports. To solve the problem of residual material, the tank liquid nest set up in the bottom of tank truck.

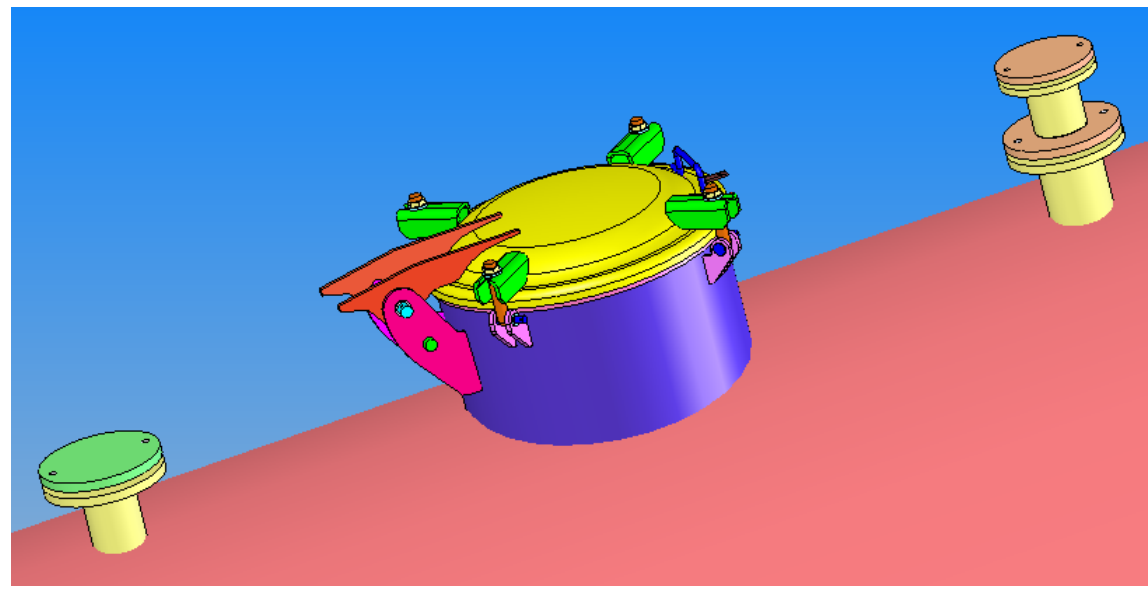

Fig.1 The manhole and nitric acid at the top of tank

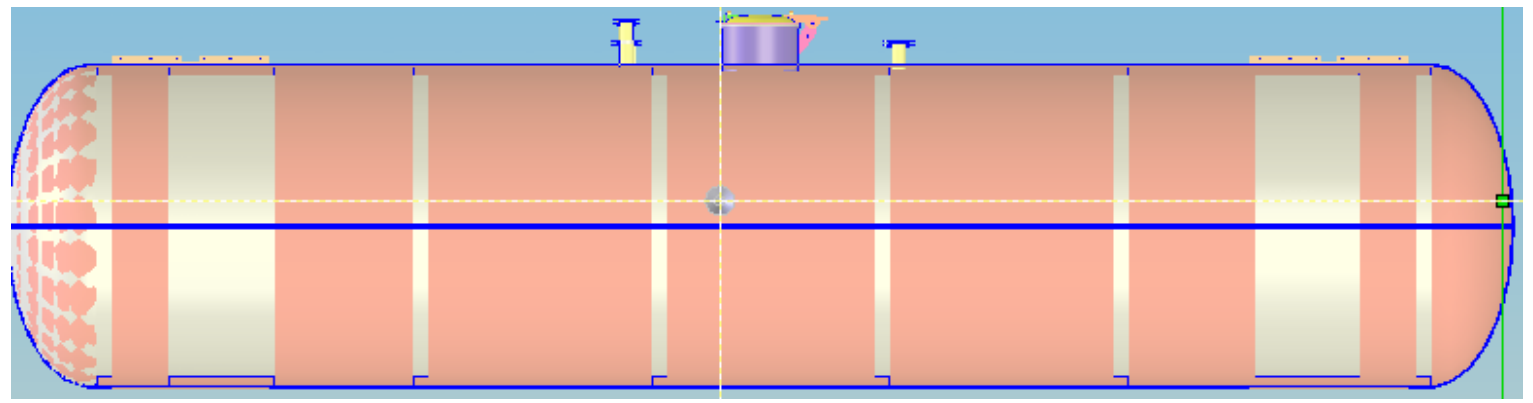

Fig.2 3D Tank assembly figure

The chassis assembly. The vehicle chassis compound by the centre sill, side beam, pillow beam, beam, tank truck through the railing, counter etc. Centre sill use high strength hot rolled steel, yield strength is $450 \mathrm{Mpa}$, in $-40^{\circ} \mathrm{C}$ low temperature impact $A_{K V}$ should not less than $24 \mathrm{~J}$; upper core plate using forged steel upper core plate; body bolster is double web box structure, assembly welding with the cover plate, the plate, web plate baffle plate and steel plate, the material is Q345A high strength low. Side beam type use $160 \times 160 \times 6.5$ hot rolled steel channel. 


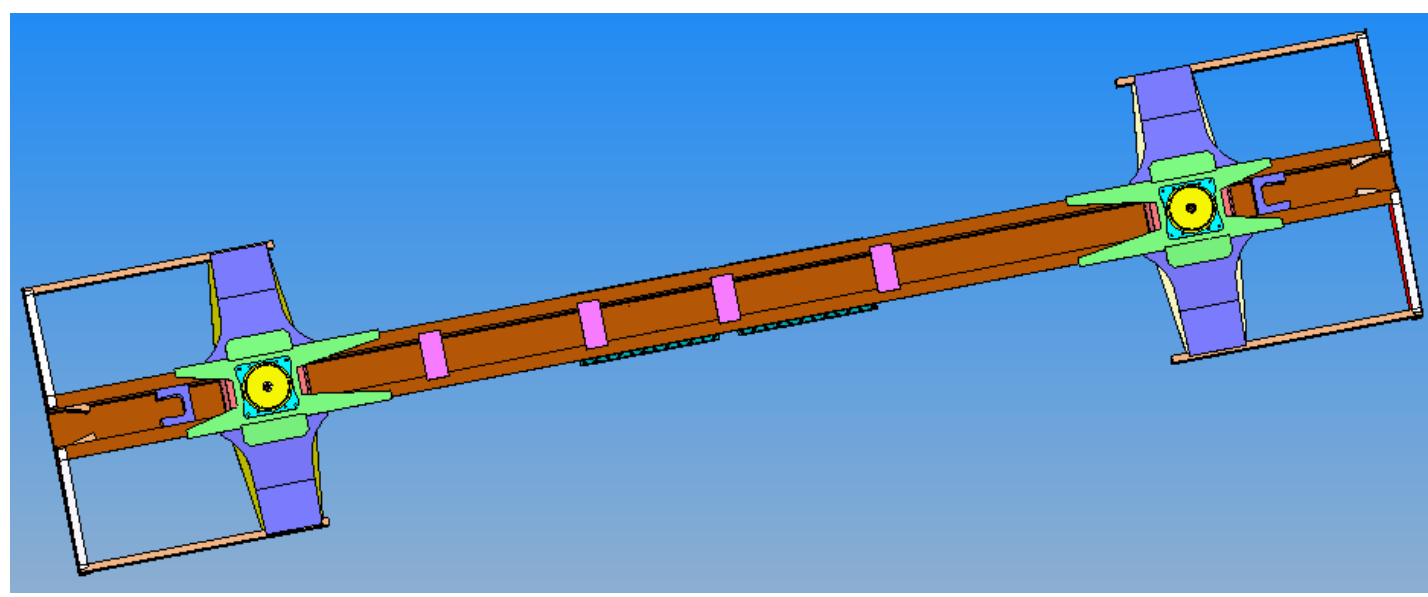

Fig.3 3D Chassis assembly figure

Tank and chassis assembly. Tanks connected with the chassis are combined with longitudinal wood and elastic taut take part in the pillow beam. Vertical wooden seat in the corresponding parts and chassis pillow beam center. Tanks and chassis to combination with vertical wooden bridge, Angle is $120^{\circ}$. Connection taut band and chassis is done through the bracket and bolts and other fasteners, connecting the tanks on the saddle and saddle under the chassis is through bolts, end bracket on both ends of tanks is respectively set up support to limit tanks head longitudinal and vertical displacement. Uses the steel plate fastening of tank, $1200 \mathrm{~mm}$ wide, $10 \mathrm{~mm}$ thick, the material for Q345A.

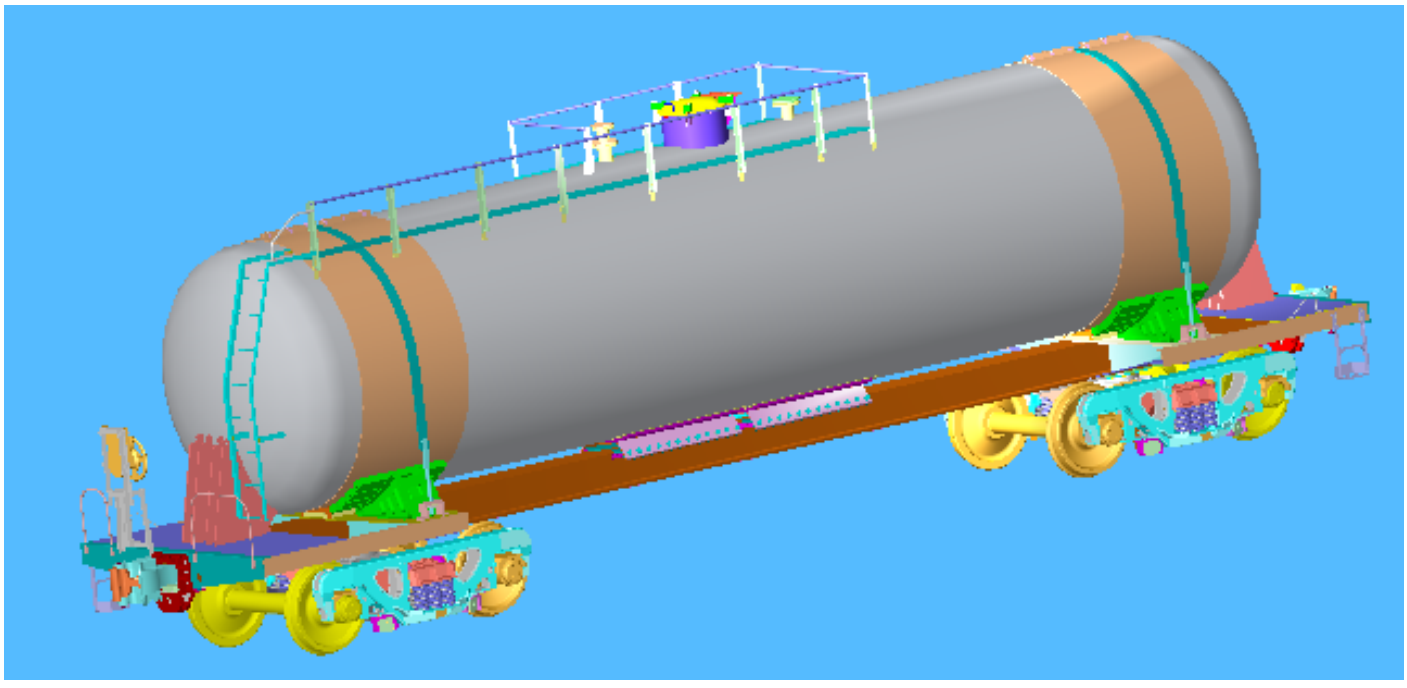

Fig. 4 Concentrated nitric acid tank truck 3D diagram

\section{Summary}

According to the results of finite element analysis and the calculation of the load condition of the body and its action mode, we found that the tanks and car body can meet the strength requirements both.

\section{References}

[1] WANG Da-hong, YU Ming, ZHANG Fu-dong, Optimization Design of the Aluminum Tanker of 23 t Axle Load for Concentrated Nitric Acid, J. RAILWAY LOC0M0TIVE\& CAR Oct(2012) 